\title{
PENERAPAN RAPID APPLICATION DEVELOPMENT PADA PERANCANGAN SISTEM INFORMASI PEMBELIAN BARANG (SI BERANG)
}

\author{
Lydia Salvina Helling \\ Sistem Informasi Akuntansi, Universitas Bina Sarana Informatika \\ Email: 1ydia.1sh@bsi.ac.id
}

DOI: https://doi.org/10.46880/jmika.Vol5No2.pp116-124

\begin{abstract}
TB. Kranggan Jaya is one form of company engaged in the sale and purchase of building goods where the buying and ordering process that occurs so far is still manual. Recording and calculations in transactions that require accuracy, often get into trouble to the detriment of the store. This is what underlies the need for a process that runs automatically with the use of information systems. The construction of SIBeRang for TB. Kranggan Jaya is urgently needed to answer the challenges faced in business competition in businesses related to building shops. The rapid application development method is used in software development and data collection through direct observation of the purchasing process, ordering goods until the goods ordered are received by the warehouse. In this study, in addition to interviews with warehouse employees and purchases. SIBeRang finally overcome this problem so that the existing data becomes accurate and can be accounted for. In addition to TB. Kranggan Jaya, suppliers benefit from this information system by making it easy to obtain data on ordering goods without having to come to take documents to the building shop.
\end{abstract}

Keyword: Purchasing, Information System, Ordering, Building Goods, Rapid Application Development.

\section{ABSTRAK}

TB. Kranggan Jaya adalah salah satu bentuk perusahaan yang bergerak dibidang jual beli barang bangunan dimana proses pembelian dan pemesanan yang terjadi selama ini masih bersifat manual. Pencatatan dan perhitungan dalam transaksi yang memerlukan keakuratan, sering mendapatkan masalah sehingga merugikan pihak toko. Hal inilah yang mendasari dibutuhkannya proses yang berjalan otomatis dengan penggunaan sistem informasi. Pembangunan SIBeRang bagi TB. Kranggan Jaya sangat dibutuhkan untuk menjawab tantangan yang dihadapi dalam persaingan bisnis di usaha yang terkait dengan toko bangunan. Metode rapid application development digunakan dalam pembangunan perangkat lunaknya dan pengumpulan data melalui pengamatan langsung pada proses pembelian, pemesanan barang sampai barang yang dipesan diterima oleh gudang dilakukan pada penelitian ini disamping wawancara kepada karyawan gudang dan pembelian. SIBeRang akhirnya mengatasi masalah ini sehingga datadata yang ada menjadi akurat dan dapat dipertanggung jawabkan. Selain TB. Kranggan Jaya, pihak pemasok mendapatkan keuntungan dari sistem informasi ini dengan kemudahan dalam memperoleh data pemesanan barang tanpa harus datang mengambil dokumen ke toko bangunan tersebut.

Kata Kunci: Pembelian, Sistem Informasi, Pemesanan, Barang Bangunan, Rapid Application Development.

\section{PENDAHULUAN}

Pada suatu perusahaan bisnis, transaksi pembelian dan pengadaan merupakan suatu proses yang memiliki periode dalam pelaksanaannya, tergantung kebutuhan perusahaan. Pembelian merupakan suatu usaha yang dilakukan untuk mendatangkan barang yang dibutuhkan oleh perusahaan (Aryadi \& Wahyuni, 2019). Transaksi pembelian (purchasing) memiliki aktifitas yang berbeda dengan transaksi pengadaan (procurement). Pengadaan dimulai dari perencanaan strategis, pengadaan tender, pemilihan vendor, negosiasi pembayaran, pembuatan kontrak perjanjian kerjasama, penilaian barang atau jasa yang akan terpilih, pembelian barang atau jasa, penerimaan barang atau jasa, proses pembayaran kepada vendor, dan penilaian kerja vendor. Sedangkan pembelian memiliki aktifitas pemilihan vendor, pemesanan barang, penerimaan DO (Delivery Order) dan memantau pesanan, menerima barang dan melakukan pemeriksaan, pengecekan 3 arah: invoice dan DO serta pembayaran tagihan/faktur. Jadi bisa dikatakan bahwa pembelian merupakan tahapan dalam proses pengadaan (PPHBI, 2020) .

Toko Bangunan Kranggan Jaya adalah sebuah toko yang menjual berbagai jenis bahan bangunan dan perkakas untuk membuat bangunan seperti pasir, 
semen, berbagai macam kayu, paku, cat, sekop, palu dan berbagai kebutuhan bangunan lainnya. Transaksi penjualan dan pembelian barang yang ada di toko tersebut masih mempergunakan cara manual dalam proses pencatatan transaksinya sehingga rentan terhadap kesalahan perhitungan, kehilangan dokumen dan kerusakan pada buku rekapnya (Hartini \& Sarjono, 2016). Pencarian dokumen pun memerlukan waktu untuk mendapatkannya sehingga kurang efisien dalam penggunaan waktu kerja. Pelayanan terhadap konsumen menjadi sedikit terganggu dikarenakan informasi tentang ketersediaan barang yang kurang akurat dan belum adanya pengkodean barang pada buku catatan stok barang (Setiawan, Retnoningsih, Herlawati, \& Retnoningsih, 2017).

Berdasarkan permasalahan tersebut, maka perancangan sistem informasi pembelian barang bangunan menjadi solusi terbaik agar dapat bersaing dengan toko bangunan lain yang sudah menggunakan teknologi informasi dalam transaksi bisnisnya (Hakim, Febriani, \& Solechan, 2019). Sistem Informasi Pembelian Barang Bangunan ini juga akan mengatasi masalah efisiensi waktu dalam pencarian data dan efektifitas dalam penyimpanan data serta pengolahannya.

\section{TINJAUAN PUSTAKA}

Software Development Life Cycle (SDLC) adalah suatu metode yang biasa digunakan oleh sistem analis dan programmer dalam membangun atau mengembangkan sebuah sistem atau perangkat lunak. Ada 6 kegiatan umum yang sering terdapat dalam SDLC, yaitu: analisis sistem, disain spesifikasi kebutuhan sistem, konstruksi sistem, implementasi sistem, pengujian sistem, dan pemeliharaan sistem (Dwanoko, 2016) . Berbagai macam bentuk metode pengembangan perangkat lunak, seperti: Linear Sequential Model atau Waterfall, Incremental Process, Evolutionary Process, Rapid Application Development, Concurrent Model, dan masih banyak yang lainnya (Bolung \& Tampangela, 2017).

Rapid Application Development (RAD) merupakan metode pengembangan perangkat lunak yang memerlukan waktu singkat dalam prosesnya sehingga waktu normal minimal 180 hari dapat dipersingkat menjadi 60 - 90 hari (Fadli, 2018).

\section{METODE PENELITIAN}

Model eksperimen dipilih untuk menjadi metode penelitan kali ini dimana langkah pertamanya adalah dengan menganalisa sistem berjalan saat ini yang kemudian dikembangkan menjadi sistem informasi yang lebih baik sesuai dengan kebutuhan penggunanya.

\section{Jenis Penelitian}

Model Prosedural yang digunakan dalam penelitian ini memiliki sifat deskriptif yang menghasilkan produk tertentu.

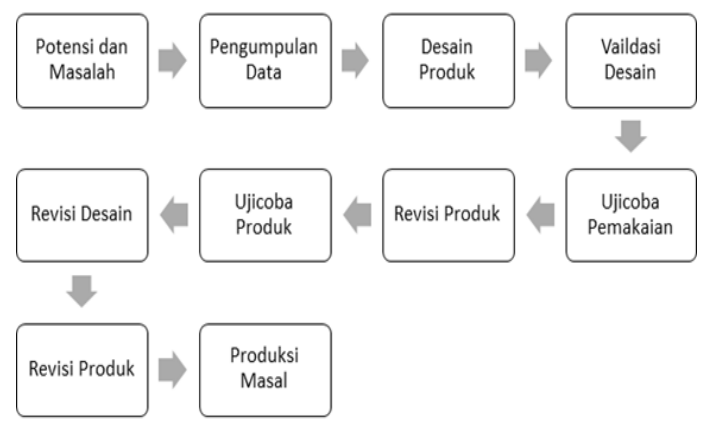

Sumber : (Hanafi, 2017)

Gambar 1. Model Research And Development $(R \& D)$

Gambar 1 merupakan gambaran dari model penelitian dan pengembangan (Research And Development) Borg Dan Gall yang akan menghasilkan sebuah produk serta menguji keefektifan produk tersebut (Haq, 2016).

\section{Metode Pengembangan Perangkat Lunak}

Pada gambar 2 memperlihatkan metode yang digunakan dalam proses pengembangan perangkat lunak ini adalah System Development Life Cycle (SDLC) bertipe Rapid Application Developmnet (RAD) yang sesuai dengan kondisi pada TB. Kranggan Jaya dimana permasalahan yang diangkat hanya lingkup kecil dan tim pengembang sistem yang terbatas (Kusaeri, Juliana, \& Pratama, 2018) serta waktu yang relatif singkat (Aswati, Ramadhan, Firmansyah, \& Anwar, 2017). Langkah - langkah yang ada di dalam RAD adalah sebagai berikut: (Irnawati \& Listianto, 2018)

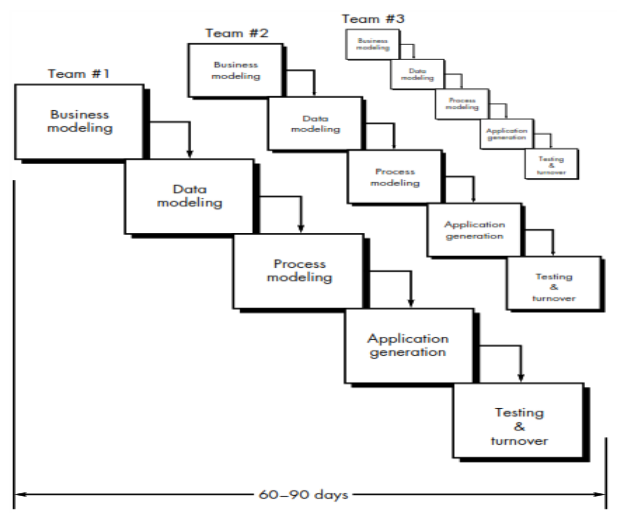

Sumber: (Pressman, 2012)

Gambar 2. Rapid Application Development (RAD) 
Penjelasan Gambar:

1. Pemodelan Bisnis

Pemodelan yang dilakukan untuk memodelkan fungsi bisnis untuk mengetahui informasi apa saja yang harus dibuat, siapa yang harus membuat informasi itu, bagaimana alur informasi itu, proses apa saja yang terkait dengan informasi itu.

2. Pemodelan Data

Memodelkan data apa saja yang dibutuhkan berdasarkan pemodelan bisnis dan mendefinisikan atribut-atributnya beserta relasinya dengan data data yang lain

3. Pemodelan Proses

Mengimplementasikan fungsi bisnis yang sudah didefinisikan terkait dengan pendefinisian data.

4. Pembuatan Aplikasi

Mengimplementasikan pemodelan proses dan data menjadi program. Model RAD sangat menganjurkan pemakaian komponen yang sudah ada jika dimungkinkan.

5. Pengujian dan Pergantian

Menguji komponen - komponen yang dibuat, Jika sudah teruji, maka tim pengembang komponen dapat beranjak untuk mengembangkan komponen berikutnya.

\section{Metode Pengumpulan Data} meliputi:

Metode pengumpulan data pada penelitian ini

1. Pengamatan secara langsung/observasi

Mengamati secara langsung tahap demi tahap pada proses pemesanan barang kepada pemasok dengan membuat surat permintaan barang, melihat proses pencatatan di buku stok barang saat barang yang dipesan telah tiba di toko.

2. Wawancara

Melakukan wawancara kepada karyawan yang bekerja saat proses pemesanan dan penerimaan barang berlangsung.

3. Studi Pustaka

Membaca beberapa jurnal yang membahas tentang pengembangan sistem informasi pembelian barang

\section{Lokasi Penelitian}

TB.Kranggan Jaya adalah sebuah toko bangunan yang terletak di pertigaan Saan, Jl.Lurah Namat, Rt 2 rw 9, Jatirangga, Kec. Jatisampurna, Kota Bekasi, Jawa Barat.

\section{HASIL DAN PEMBAHASAN}

Pelaksanaan langkah demi langkah metode SDLC tipe RAD yaitu:

\section{Pemodelan Bisnis}

Pada tahap ini proses analisa dilakukan sehingga menghasilkan beberapa kebutuhan untuk sistem informasi yang akan dibangun. Prosedur sistem pembelian dari sistem yang berjalan saat ini meliputi:

1. Prosedur Permintaan Barang

Bagian gudang mengisi form permintaan barang yang berisi nama - nama barang yang dibutuhkan gudang untuk dibeli. Form tersebut kemudian diberikan ke bagian keuangan untuk ditinjau kembali. Form yang telah disetujui oleh pihak keuangan kemudian diberikan ke pemilik toko bangunan untuk dibubuhi tanda tangan persetujuan pemesanan barang. Form tersebut kemudian dikembalikan ke bagian keuangan untuk diteruskan ke bagian pembelian (gambar 3).

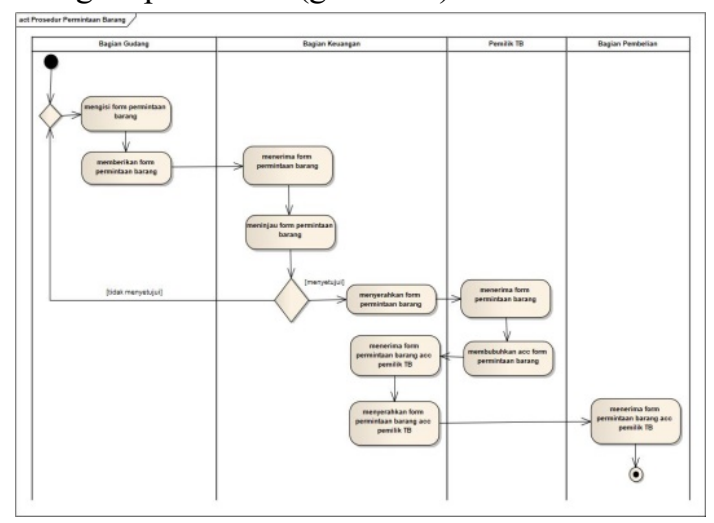

Gambar 3. Activity Diagram Prosedur Permintaan Barang Sistem Berjalan

2. Prosedur Pemesanan Barang

Form permintaan barang yang telah diterima oleh bagian pembelian kemudian ditindak lanjuti dengan mengubungi sales dari perusahaan pemasok barang. Sales kemudian akan menginformasikan keberadaan barang yang dipesan kepada bagian pembelian. Bila seluruh barang yang dipesan tersedia, maka bagian pembelian akan membuatkan Purchasing Order (PO) untuk kemudian diserahkan ke sales dari perusahaan pemasok barang tersebut, PO asli dan tembusan 2. Jika tidak, maka bagian pembelian mengembalikan form permintaan barang tersebut ke bagian keuangan untuk kemudian diserahkan ke bagian gudang agar direvisi sesuai dengan ketersediaan barang yang ada pada pemasok. Tembusan ke 3 dari PO akan disimpan oleh bagian pembelian, sedangkan tembusan ke 4 nya akan diserahkan ke bagian gudang (gambar 4). 


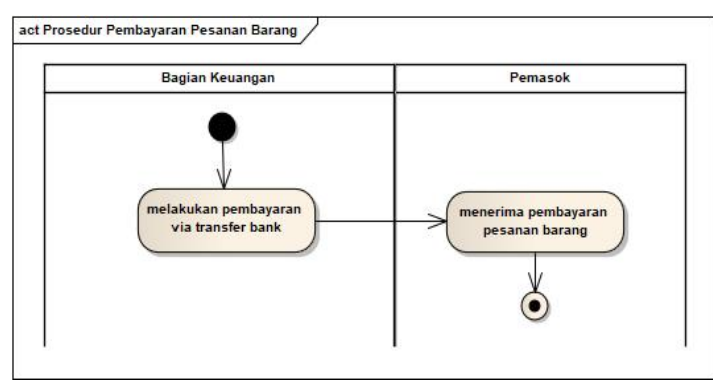

Gambar 4. Activity Diagram Prosedur Pembayaran Pesanan Barang Sistem Berjalan

3. Prosedur Penerimaan Barang

Barang yang datang dari pemasok akan diterima oleh bagian gudang. Bagian pengiriman dari pemasok akan menyerahkan surat jalan asli, faktur penjualan asli, dan tembusan ke 2 dari PO. Semua dokumen ini akan dicocokkan oleh bagian gudang dengan tembusan ke 4. Barang yang diterima pun akan mengalami pengecekan oleh bagian gudang. Jika barang sesuai pesanan dan dalam keadaan baik, maka bagian gudang akan mengembalikan tembusan surat jalan dan tembusan faktur penjualan ke bagian pengiriman dari pihak pemasok, menyerahkan faktur penjualan asli dan tembusan ke 2 PO ke bagian pembelian yang kemudian diberikan ke bagian keuangan. Jika barang yang diterima dalam keadaan rusak atau tidak sesuai pesanan, maka bagian gudang akan mengembalikan barang yang rusak atau tidak sesuai pesanan ke bagian pengiriman untuk dimintakan faktur retur. Bagian gudang juga akan memperbaharui data stok pada buku stok barang (gambar 5).

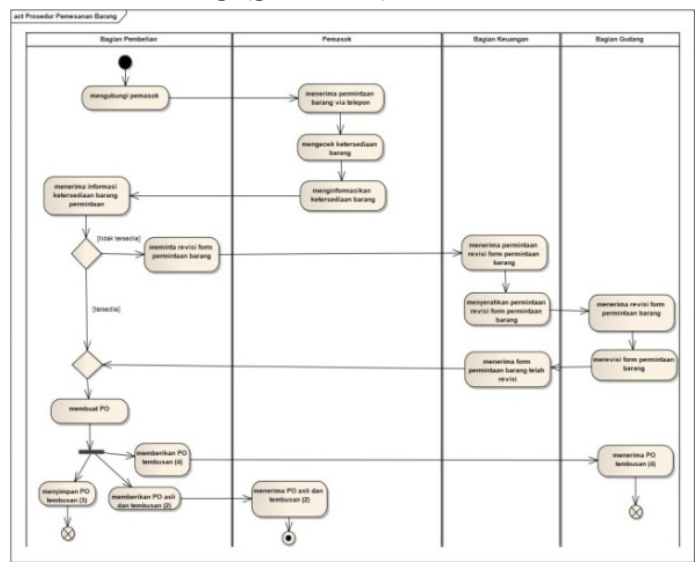

Gambar 5 Activity Diagram Prosedur Pemesanan Barang Sistem Berjalan

4. Prosedur Pembayaran Pesanan Barang

Bagian keuangan kemudian akan melakukan pembayaran seperti tanggal yang tertera di faktur penjualan dari pihak pemasok (gambar 6).

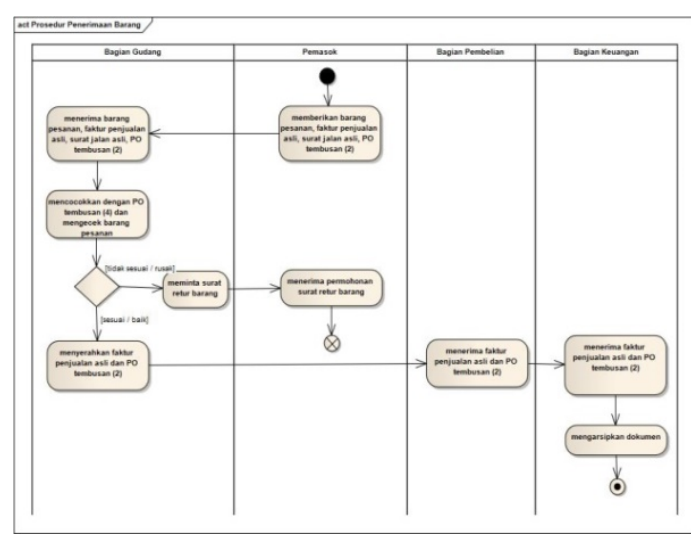

Gambar 6. Activity Diagram Prosedur Penerimaan Barang Sistem Berjalan

5. Prosedur Pembuatan Laporan

Pada akhir bulan, bagian gudang akan membuat laporan permintaan barang, penerimaan barang dan stok barang. Bagian pembelian akan membuat laporan pemesanan barang, sedangkan bagian keuangan akan membuat laporan pembayaran pemesanan. Laporan - laporan tersebut kemudian diberikan ke pemilik toko bangunan (gambar 7)

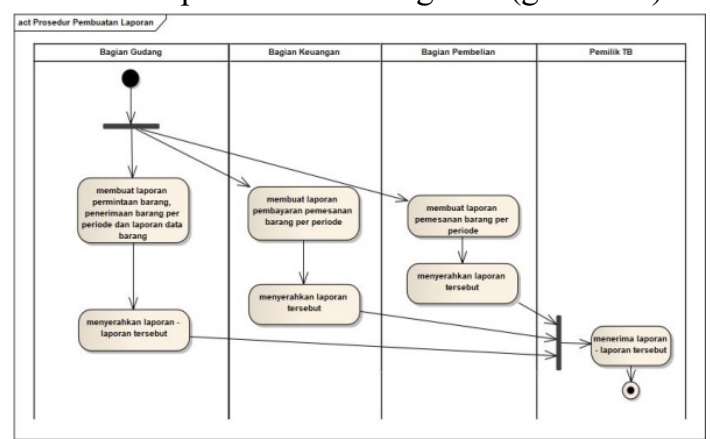

Gambar 7. Activity Diagram Prosedur Pembuatan Laporan Per Bulan Sistem Berjalan

Berdasarkan analisis yang dilakukan pada sistem pembelian yang berjalan saat ini, maka didapatkanlah kebutuhan dari para pengguna pada sistem informasi pembelian barang yang dibangun, yaitu:

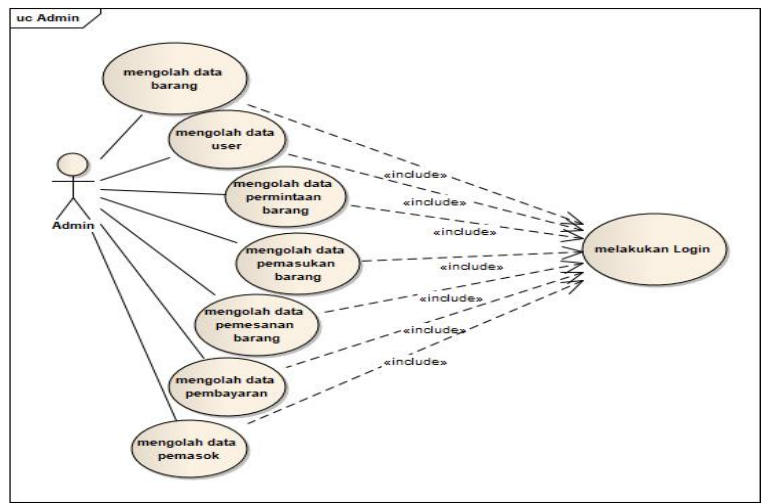

Gambar 8. Use Case Diagram untuk Bagian Admin 
Gambar 8. menjelaskan seluruh fasilitas yang digunakan oleh pihak admin dalam mengatur seluruh data, seperti data pemasok, data user, data barang, data permintaan barang, data pemesanan barang, data pemasukan barang, dan data pembayaran.

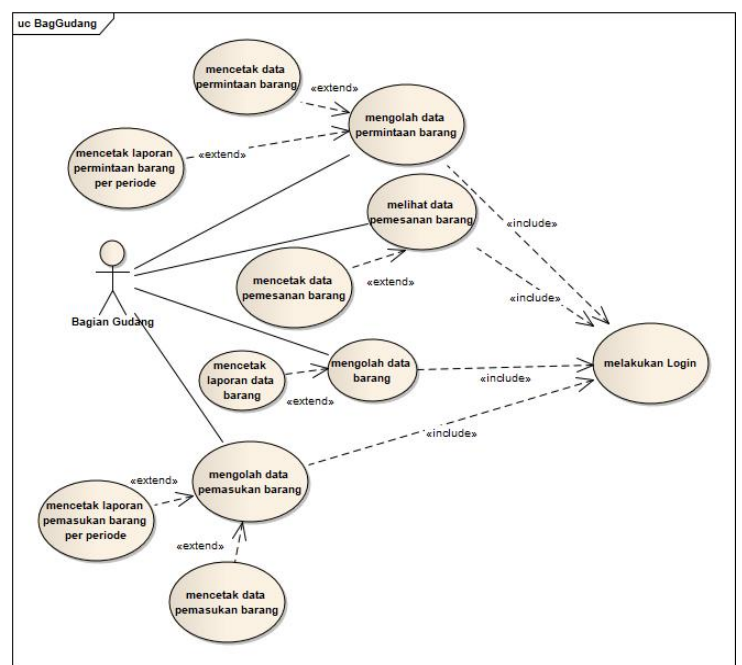

Gambar 9. Use Case Diagram untuk Bagian Gudang pada SIBeRang

Gambar 9 menjelaskan kebutuhan bagian gudang pada SIBeRang, seperti mengolah data permintaan barang dan mencetaknya, serta dapat membuat laporan permintaan barang per periode tertentu. Bagian gudang juga dapat melihat data pemesanan barang serta mencetaknya, mengolah data barang serta dapat mencetak laporan data barang. Fasilitas pengolahan data pemasukan barang, mencetaknya, membuat laporan pemasukan barang per periode tertentu juga diberikan untuk bagian gudang.

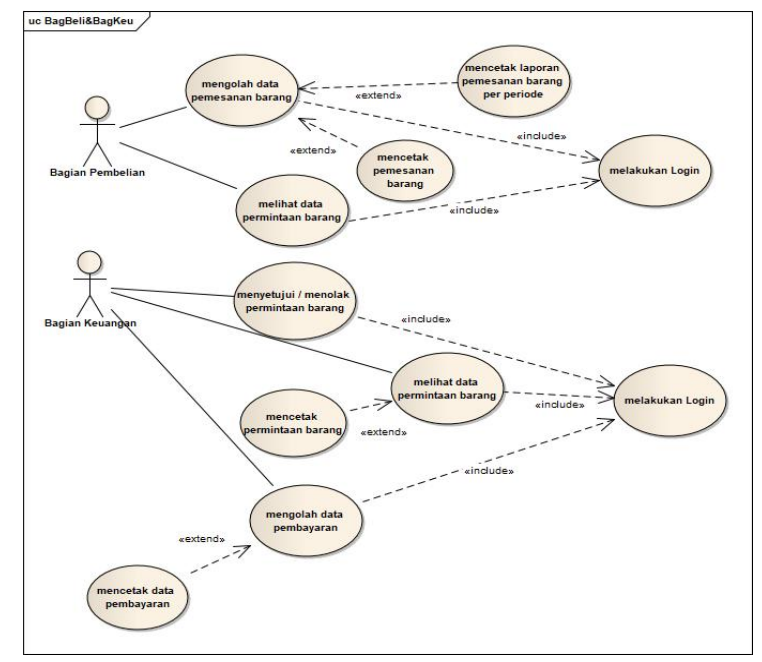

Gambar 10. Use Case Diagram untuk Bagian Pembelian dan Bagian Keuangan pada SIBeRang
Gambar. 10 menjelaskan kebutuhan Bagian Pembelian dan Bagian Keuangan pada SIBeRang. Bagian Pembelian harus bisa mengolah data pemesanan barang serta mencetaknya, bahkan bisa pula mengeluarkan laporan pemesanan barang untuk periode tertentu. Sedangkan Bagian Keuangan harus difasilitasi dalam mengolah data pembayaran serta mencetaknya, melihat data permintaan barang dan juga mencetaknya. Bagian gudang juga harus bisa mengubah status dari permintaan barang tersebut menjadi disetujui.

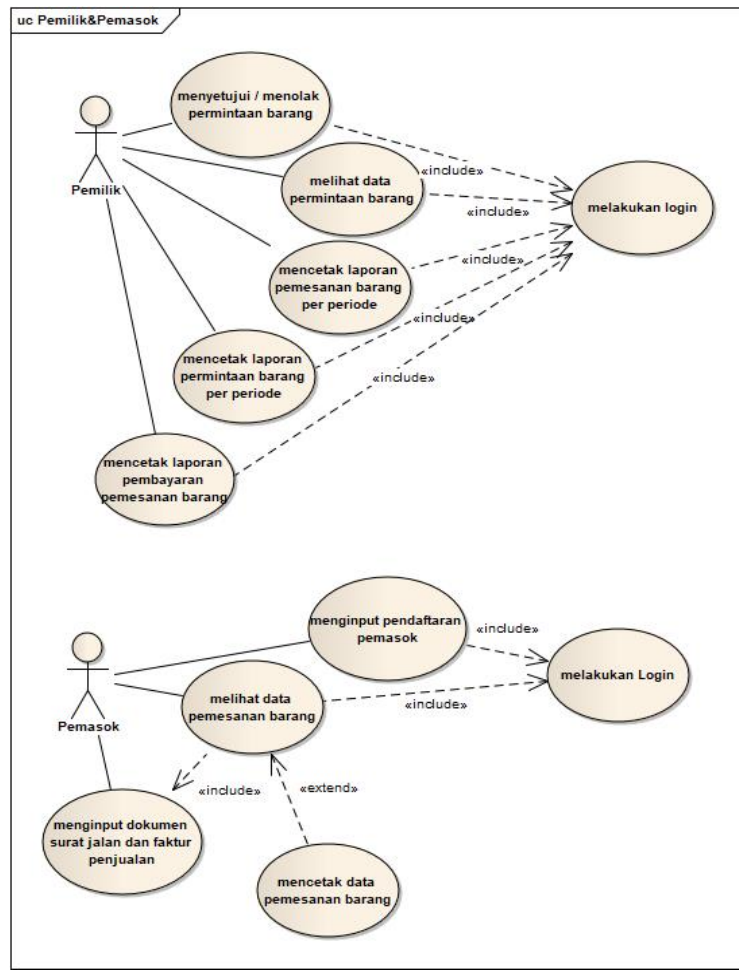

Gambar 11. Use Case Diagram untuk Pemilik TB dan Pemasok pada SIBeRang

Pada gambar 11 menjelaskan tentang kebutuhan pemilik toko bangunan dan pemasok dalam SIBeRang ini. Pemilik toko bangunan dapat melihat data permintaan barang serta mengubah status dari permintaan barang tersebut menjadi disetujui atau tidak. Berbagai macam bentuk laporan, seperti: permintaan barang, pemesanan barang, pembayaran pesanan barang disediakan untuk pemilik toko dengan periode tertentu yang diperlukan. SIBeRang juga menyediakan pendaftaran bagi pemasok yang akan mempergunakan sistem informasi ini, selain dapat melihat pemesanan barang dan mencetaknya. Pemasok juga diberi fasilitas untuk memasukkan dokumen surat jalan dan faktur penjualan yang nanti akan menjadi bukti ketika sampai toko bangunan Kranggan Jaya. 


\section{Pemodelan Data}

Pada tahap ini dilakukan rancangan database yang merupakan hasil dari analisa kebutuhan pengguna sistem informasi pada pemodelan bisnis. Entity Relationship Diagram dibawah ini menggambarkan hubungan beberapa entitas yang berupa tabel - tanel pada SIBeRang.

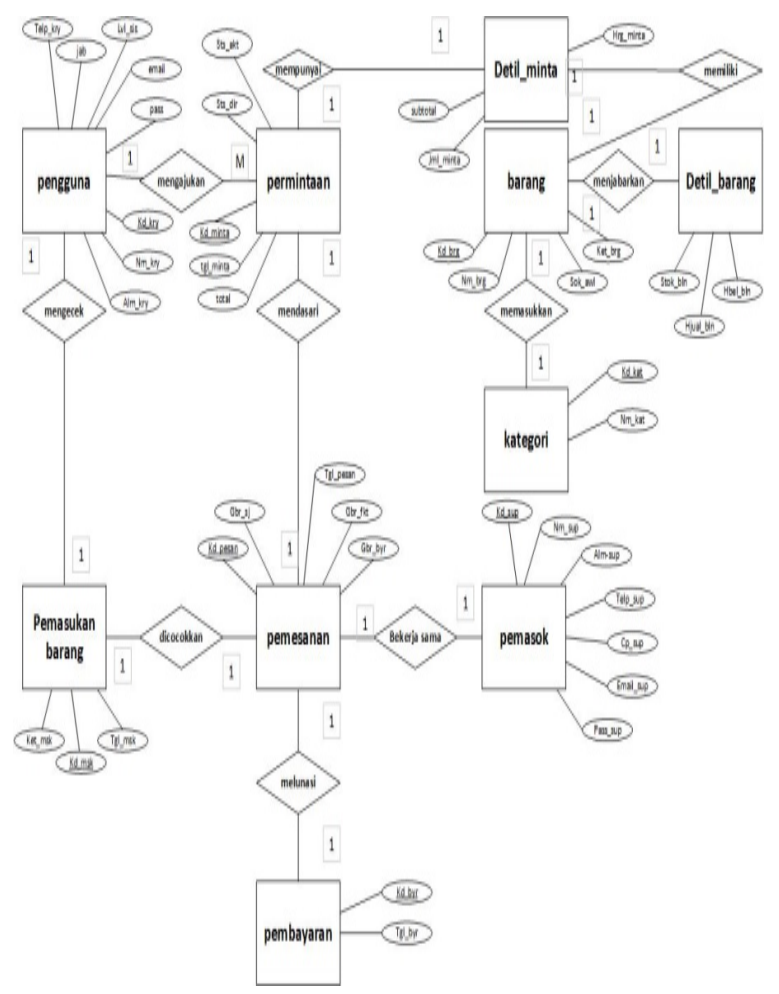

Gambar 12. Entity Relationship Diagram untuk SIBeRang

Pada gambar 12 menggambarkan beberapa entitas yang terbentuk, yaitu: tabel pengguna, tabel permintaan, tabel detil_minta, tabel barang, tabel detil_barang, tabel kategori, tabel pemasukan_barang, tabel pemesanan, tabel pemasok, tabel pembayaran. Setiap 1 karyawan mengajukan beberapa permintaan dimana tiap pemintaan mempunyai 1 detil dan tiap detil memiliki 1 kode barang yang tiap barangnya masing masing menjabarkan 1 detil barang serta masuk dalam 1 kategori. Tiap 1 permintaan mendasari 1 pemesanan yang menjelaskan kerja sama untuk tiap 1 pemasok. Tiap 1 pemesanan akan dilunasi masing - masing pembayarannya dan tiap pemesanan akan dicocokkan masing - masing pada tiap proses pemasukan barang yang dilakukan oleh 1 orang karyawan.

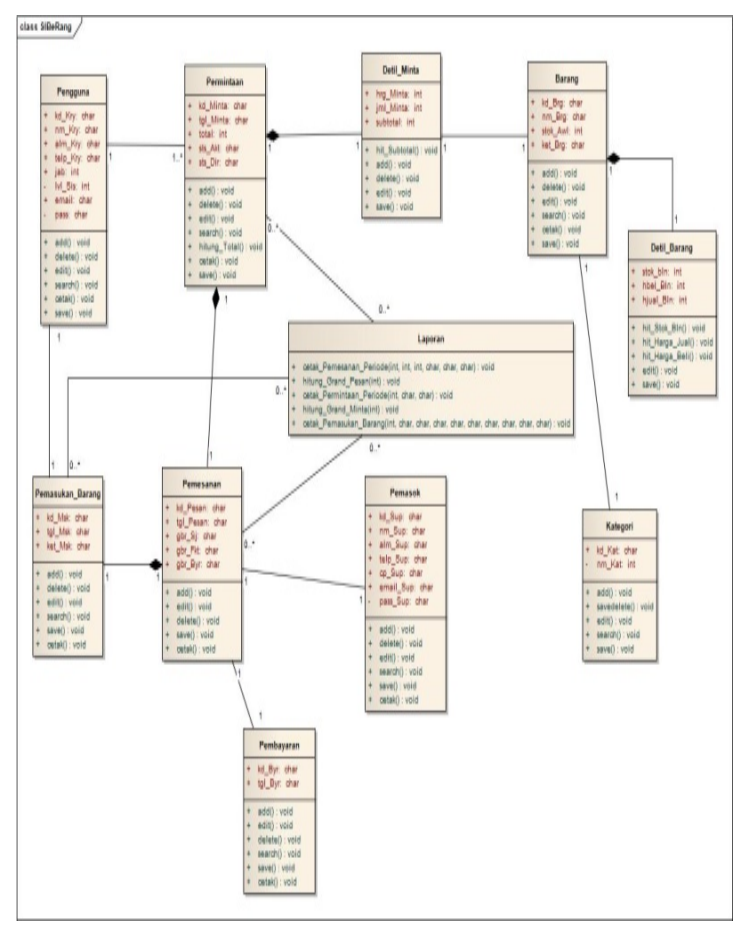

Gambar 13 Class Diagram pada SIBeRang

Pada gambar 13 diuraikan hubungan antar masing - masing kelas dalam SIBeRang dimana 1 data pengguna akan memiliki hubungan dengan minimal 1 data permintaan atau maksimal banyak data permintaan, seluruh data permintaan merupakan bagian dari seluruh data detil_minta, 1 data detil_minta berelasi dengan 1 data barang dimana seluruh data barang merupakan bagian dari seluruh data detil_barang. Setiap data barang akan memiliki hubungan dengan setiap data kategori. Seluruh data di permintaan merupakan bagian dari seluruh data pemesanan. Seluruh data pemesanan juga merupakan bagian dari seluruh data pemasukan_baranng. 1 data permesanan mempunyai 1 data pembayaran dimana tiap data permintaan juga memiliki 1 data pemasok. 1 data pemasukan pasti hanya dikerjakan oleh satu data pengguna.

\section{Pemodelan Proses}

Pada tahap ini, proses yang berlangsung dalam SIBeRang akan memiliki prosedur di bawah ini:

\section{Prosedur Pendaftaran}

Pihak pemasok yang menjadi mitra TB. Kranggan Jaya harus melakukan pendataan di website yang sudah disediakan. Admin kemudian akan memberikan kode pemasok setelah semua data dimasukkan oleh pemasok.

2. Prosedur Permintaan Barang

Pihak gudang akan mengisi form permintaan barang di website yang kemudian isian tersebut 
diperiksa oleh bagian keuangan.Bagian keuangan kemudian mengubah sts_Akt menjadi 'ok' bila setuju. Data ini kemudian di buka oleh pihak pemilik toko untuk mengubah pula sts_Dir menjadi 'ok'.

3. Prosedur Pemesanan Barang

Bagian pembelian kemudia melihat data permintaan yang telah disetujui oleh bagian keuangan dan pemilik toko, bila sudah 'ok' maka bagian pembelian menghubungi pihak pemasok untuk mengecek ketersediaan barang. Bila seluruh barang tersedia, maka bagian pembelian mulai menginput data pemesanan berdasarkan data pembelian. Dan bila tidak tersedia, maka pihak gudang bisa melakukan perubahan di data permintaan. Data pemesanan yang telah dimasukkan, kemudian akan dibuka oleh pemasok untuk dibuatkan surat jalan dan faktur penjualan. Setelah 2 dokumen ini dibuat, pemasok kemudian akan meng upload dokumen tersebut dalam data pemesanan.

4. Prosedur Pemasukan Barang

Pihak gudang kemudian akan menerima barang yang dikirim oleh pemasok dengan melihat data pemesanan barang. Setelah semua barang sudah dicek dan dalam keadaan baik, bagian gudang kemudian meng input data pemasukan barang berdasarkan data pemesanan barang.

5. Prosedur Pembayaran Pesanan

Bagian keuangan akan melakukan pembayaran pemesanan barang sesuai jatuh tempo yang tertera pada bukti faktur penjualan yang ada pada data pemesanan barang. Setelah bagian keuangan sudah melakukan pembayaran, maka harus meng upload bukti pembayaran tersebut di form pemesanan barang. Bukti pembayaran ini dapat dilihat oleh pihak pemasok sebagai bukti bahwa toko bangunan telah melunasi barang yang dipesan.

6. Prosedur Pembuatan Laporan

Pemilik toko bangunan kapanpun bisa mencetak laporan permintaan barang, laporan pemesanan barang, laporan pemasukan barang, dan laporan pembayaran pesanan barang.

\section{Pembuatan Aplikasi}

Pada tahap ini, hasil dari pemodelan proses diimplementasikan dalam bentuk rancangan program. Beberapa tampilan di uraikan di bawah ini:

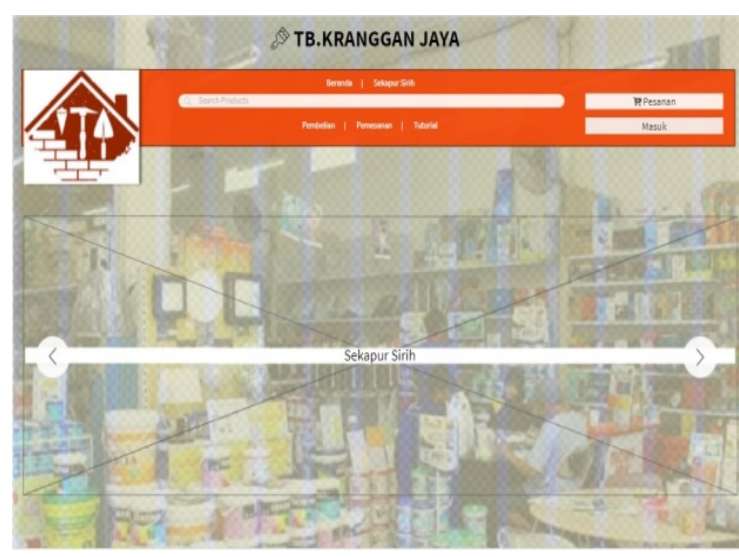

Gambar 14. Tampilan Halaman Beranda

Gambar 14 memperlihatkan tampilan halaman Beranda yang diperuntukkan bagi bagian gudang, bagian pembelian, dan bagian keuangan. Halaman ini berhubungan dengan transaksi internal yang terjadi di TB.Kranggan Jaya. Pada halaman ini terdapat menu pembelian yang tidak terdapat di halaman Beranda untuk Pemasok. Pada Halaman Beranda untuk pemasok, menu pembelian digantikan oleh menu pendaftaran.

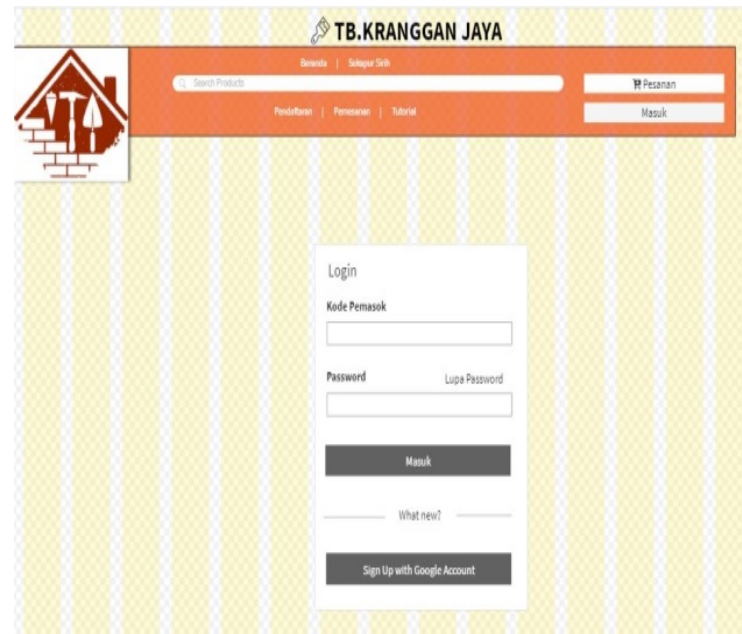

Gambar 15. Tampilan Form Login

Gambar 15 menampilan Form Login untuk pemasok setelah melakukan pendaftaran pada menu bar yang ada di SIBeRang. Kode pemasok akan diberikan pihak admin TB.Kranggan Jaya setelah pemasok selesai melakukan pendaftaran. Pihak admin akan mengubungi pemasok terkait dengan pemberian kode ini.Form Login untuk pihak internal akan meminta email dan password untuk bisa masuk ke halaman SIBeRang. 


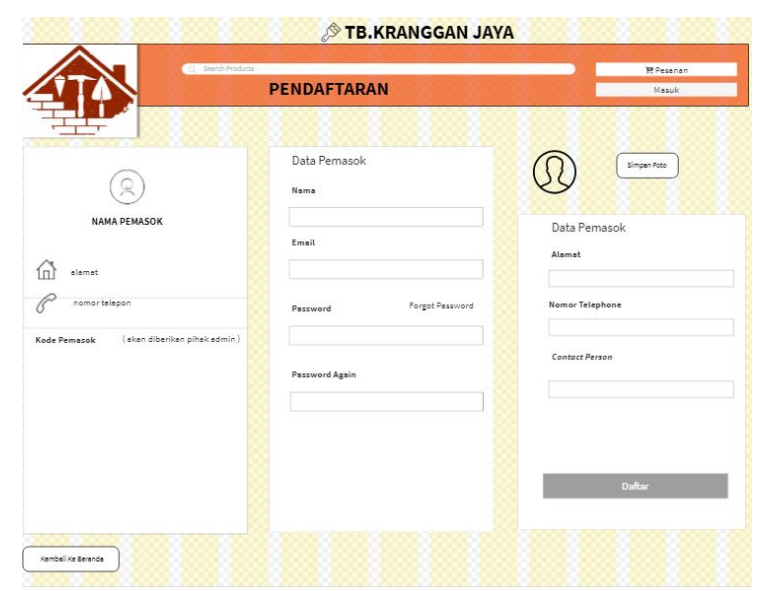

Gambar 16. Tampilan Form Pendaftaran

Gambar 16 memberikan tampilan Form Pendaftaran yang bisa diinput pertama kali oleh pemasok ketika masuk ke SIBeRang sebelum bisa mengakses menu yang lain pada Menu Bar. Form ini meminta email dan password yang nantinya akan digunakan pemasok di lain waktu ketika ada pemesanan barang dari TB.Kranggan Jaya. Form ini wajib diisi oleh pemasok sebagai bukti kerjasama dengan TB.Kranggan Jaya.

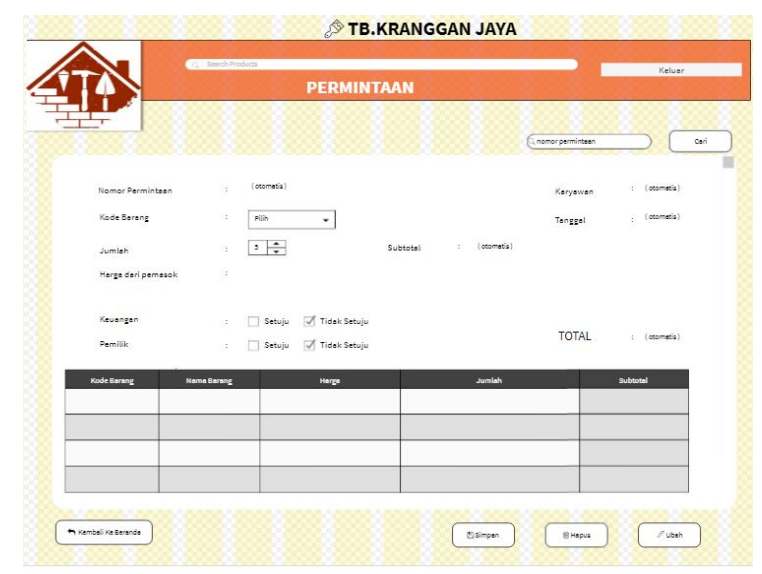

Gambar 17. Tampilan Form Permintaan

Gambar 17 merupakan tampilan Form Permintaan yang akan diisi oleh bagian gudang untuk meminta barang-barang yang dibutuhkan agar dipesan oleh bagian pembelian ke pemasok. Sebelum permintaan ini dipesan oleh bagian pembelian, bagian keuangan dan pemilik toko harus memberikan persetujuan pada isian ini. Setelah bagian pembelian melihat tanda persetujuan yang diberikan, bagian pembelian kemudian menghubungi pihak pemasok. Bila semua barang yg diinginkan tersedia, maka bagian pembelian masuk ke menu pemesanan.

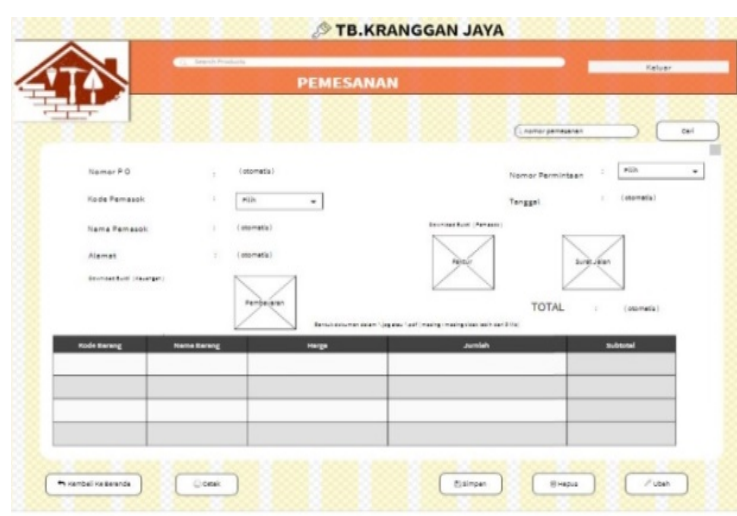

Gambar 18. Tampilan Form Pemesanan

Gambar 18 menampilkan Form Pemesanan yang harus diisi oleh bagian pembelian untuk kemudian bisa dibuka dan dicetak oleh pemasok guna keperluan menyiapkan barang yang akan dikirim ke TB.Kranggan Jaya

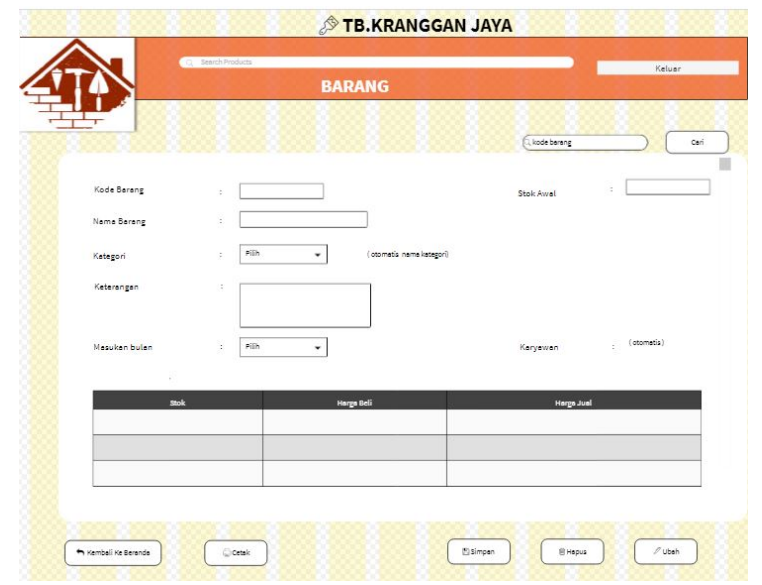

Gambar 19 Tampilan Form Barang

Gambar 19 merupakan tampikan Form Barang yang ada di sisi admin TB.Kranggan Jaya dimana seluruh data diatur pada aksi dan isiannya. Form ini akan terisi otomatis pada stok per bulan, harga jual per bulan dan harga beli per bulan yang diambil dari perhitungan pada proses pemesanan barang dan penjualan barang.

\section{Pengujian dan Pergantian}

Pada tahap ini akan dilakukan pengujian pada form-form yang berfungsi sebagai inputan dari data. Metode yang digunakan dalam pengujian ini adalah Black Box Testing untuk melihat output dari data yang diinput tanpa memperdulikan kebenaran dari output tersebut. 


\section{KESIMPULAN}

Hasil dari rancangan SIBeRang ini memberikan beberapa file yang bisa digunakan untuk menyimpan data yang sebelumnya berupa dokumen. Hal ini mengurangi penggunaan kertas dan tempat penyimpanan dokumen yang besar serta banyak.

SIBeRang memberikan kemudahan bagi TB. Kranggan Jaya dalam proses internal, seperti pembelian dan pemesanan barang. Begitu pula proses eksternalnya dengan pihak pemasok dimana pemasok tidak perlu datang ke TB.Kranggan Jaya untuk mendapatkan dokumen pemesanan barang.

SIBeRang memberikan keakuratan data dalam proses perhitungan harga jual, harga beli dan jumlah stok pada data barang.

\section{DAFTAR PUSTAKA}

Aryadi, H., \& Wahyuni, W. (2019). Tinjauan Prosedur Pembelian Barang di Bagian Purchasing pada PT. Duraconindo Pratama Jakarta. Jurnal Akuntansi Dan Manajemen, 16(02), 225-236. https://doi.org/10.36406/jam.v16i02.244

Aswati, S., Ramadhan, M. S., Firmansyah, A. U., \& Anwar, K. (2017). Studi Analisis Model Rapid Application Development Dalam Pengembangan Sistem Informasi. Jurnal Matrik, 16(2), 20. https://doi.org/10.30812/matrik.v16i2.10

Bolung, M., \& Tampangela, H. R. K. (2017). Analisa Penggunaan Metodologi Pengembangan Perangkat Lunak. Jurnal ELTIKOM, 1(1), 1-10. https://doi.org/10.31961/eltikom.v1i1.1

Dwanoko, Y. S. (2016). Implementasi Software Development Life Cycle ( Sdlc) Dalam Penerapan Pembangunan Aplikasi Perangkat. Jurnal Teknologi Informasi, 7(2), 83-94.

Fadli, S. (2018). Model Rapid Application Development Dalam Pengembangan Sistem Reservasi dan Penyewaan Kamar Hotel. Jurnal Informatika Dan Rekayasa Elektronik, 1(1), 57. https://doi.org/10.36595/jire.v1i1.33

Hakim, F. N., Febriani, Y., \& Solechan, A. (2019). Pengembangan Sistem Informasi Penjualan, Pembelian Dan Persediaan Berbasis Web. Jurnal SITECH : Sistem Informasi Dan Teknologi, 1(2), 155-160. https://doi.org/10.24176/sitech.v1i2.2625

Hanafi. (2017). Konsep Penelitian R \& D Dalam Bidang Pendidikan. Saintifika Islamica: Jurnal Kajian Keislaman, 4(2), 129-150.

Haq, M. S. (2016). PENGEMBANAGAN APLIKASI PRESENSI PEGAWAI. Jurnal Dinamika Manajemen Pendidikan, 1(1), 34-40.

Hartini, D., \& Sarjono. (2016). Analisis Dan Perancangan Sistem Informasi Penjualan Pada Pt. Jaya Mandiri Strategic. Jurnal Manajemen Sistem Informasi, 1(2), 73-83.
Irnawati, O., \& Listianto, G. B. A. (2018). Metode Rapid Application Development (RAD) pada Perancangan Website Inventory PT. SARANA ABADI MAKMUR BERSAMA (S.A.M.B) JAKARTA. Evolusi : Jurnal Sains Dan Manajemen, 6(2), 12-18. https://doi.org/10.31294/evolusi.v6i2.4414

Kusaeri, W. R., Juliana, P., \& Pratama, R. R. (2018). PERANCANGAN SISTEM INFORMASI PENJUALAN MENGGUNAKAN METODE RAPID APPLICATION DEVELOPMENT ( RAD ) DI PABRIK GENTENG UUN SUPER JATIWANGI.

PPHBI. (2020). Perbedaan Pengadaan Barang dan Jasa dengan Pembelian Barang dan Jasa. Retrieved from https://www.pphbi.com/

Pressman, R. S. (2012). Rekayasa Perangkat Lunak (Pendekatan Praktisi) (1st ed.). Yogyakarta: Andi Offset.

Setiawan, K., Retnoningsih, E., Herlawati, \& Retnoningsih, E. (2017). Sistem Informasi Persediaan, Pembelian dan Penjualan Barang Pada CV Evee Store Cileungsi. Jurnal Mahasiswa Bina Insani, 2(1), 25-36. 